Jurnal Kejuruteraan SI 1(4) 2018: 87-92

http://dx.doi.org/10.17576/jkukm-2018-si1(4)-11

\title{
Discoloration of Batik Effluent by Chemically Modified Oil Palm Empty Fruit Bunch Fibers
}

\author{
(Penyahwarnaan Efluen Batik Menggunakan Tandan Kosong Kelapa Sawit Terubah suai Kimia)
}

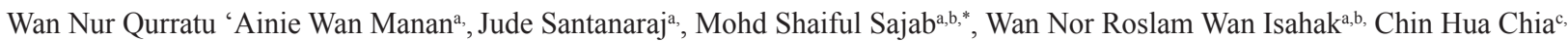 \\ ${ }^{a}$ Research Centre for Sustainable Process Technology (CESPRO), \\ ${ }^{b}$ Chemical Engineering Programme, \\ Faculty of Engineering \& Built Environment \\ ${ }^{c}$ Bioresources and Biorefinery Laboratory, School of Applied Physics, \\ Universiti Kebangsaan Malaysia
}

\begin{abstract}
In this study, oil palm biomass of empty fruit bunch (EFB) fibers was used as lignocellulosic-based material models for wastewater remediation. EFB fibers were improvised by enhancing its surface functionalization for the removal of the color in the actual effluent from the textile industry. Briefly, EFB fibers were modified using polyethyleneimine (PEI) and ethylenediaminetetraacetic acid (EDTA) to produce cationic and anionic adsorbents, respectively. The modified fibers (PEI$E F B$ and EDTA-EFB) were used to study the efficiency in removing anionic and cationic ions from the effluents at different $p H s$, temperatures and initial dye concentrations. The optimum $\mathrm{pH}$ and temperature were investigated to be at $\mathrm{pH} 3$ and $20^{\circ} \mathrm{C}$ whereas the adsorption occurred efficiently. The comparison between the modified adsorbent shows higher adsorption capacity by cationic functionalization. The charge of the PEI-EFB was positive over the entire pH range, which suggests the successful modification of the EFB fibers by PEI. In the kinetics study, the adsorption capacity of PEI-EFB fibers in the removal of color can be up to $572.3 \mathrm{mg} / \mathrm{g}$, which improved by five times of the adsorption capacity of the raw EFB fibers. Whereas, based on the experimental work and adsorption models fitting, PEI-EFB fitted on the Pseudo First-Order in comparison with the Pseudo Second-Order. Additionally, the isotherm model was fitted with the Freundlich model, contrary with the Langmuir model, its mechanism suggesting a monolayer and heterogeneous adsorption behavior of the adsorption processes.
\end{abstract}

Keywords: Adsorption; EFB; chemical treatment; dyes; textile effluent

\section{ABSTRAK}

Dalam kajian ini, biojisim gentian tandan kosong kelapa sawit (EFB) digunakan sebagai model bagi bahan berlignoselulosa untuk pemulihan air sisa. Gentian EFB telah ditambah baik dengan meningkatkan pemfungsian permukaannya untuk penyingkiran warna dalam efluen sebenar kilang tekstil. Secara ringkas, gentian EFB telah terubah suai dengan menggunakan polietilinaimina (PEI) dan asid etilinadiaminatetraasetik (EDTA) untuk menghasilkan penjerap kationik dan anionik, masingmasing. Gentian terubah suai (PEI-EFB dan EDTA-EFB) telah digunakan untuk mengkaji kecekapan dalam menyingkirkan ion anionik dan kationik daripada efluen pada pH, suhu dan kepekatan pewarna awal yang berbeza. pH dan suhu yang optimum didapati pada $\mathrm{pH} 3$ dan $20^{\circ} \mathrm{C}$ di mana penjerapan berlaku dengan lebih berkesan. Perbandingan antara penjerap terubahsuai menunjukkan keupayaan penjerapan tertinggi dengan pemfungsian kationik. Cas bagi PEI-EFB adalah positif dalam julat pH keseluruhan seterusnya mencadangkan pengubahsuaian gentian EFB oleh PEI adalah berjaya. Dalam kajian kinetik, keupayaan gentian PEI-EFB bagi penyingkiran warna mampu mencapai sehingga $572.3 \mathrm{mg} / \mathrm{g}$, iaity penambah baik sehingga lima kali ganda keupayaan penjerapan bagi gentian EFB mentah. Manakala, berdasarkan hasil eksperimen dan padanan model penjerapan, PEI-EFB menepati ke atas Pseudo Tertib-Pertama dengan pembandingan bersama Pseudo Tertib-Kedua. Tambahan lagi, model isoterma telah menepati model Freundlich, berbanding model Langmuir, di mana ianya menunjukkan lapisan mono dan tingkah laku proses penjerapan secara heterogen.

Kata kunci: Penjerapan; EFB; rawatan kimia; pewarna; efluen tekstil

\section{INTRODUCTION}

Dyes are widely used in industries such as in textile, rubber, paper, plastics, cosmetics and other industries. Altogether, the textile is second largest demands after food (Ranganathan et al. 2007). It is recognized that the public perception of the water quality is always influenced by the color. Color is the first contaminant recognized in wastewater (Banat et al. 1996). Since the biodegradation of dyes is quite ineffective, wastewater from textile industry has gained a strict attention from the authority (Ganesh et al. 1994; Weber \& Adams 1995).

There are many ways to treat wastewater effluent have been proposed and used in decolorize dyes from wastewater, 
including chemical oxidation, coagulation, photo-catalyst (Kumar et al. 2002; Wu \& Chern 2006), electrocatalyst (Ma et al. 2009), membrane filtration (Amini et al. 2011) and adsorption (Rafatullah et al. 2010). Among the methods, adsorption is the most convenient and feasible for wastewater treatment before released into the water reservoir or reuse in the processing (Ho et al. 2005).

The adsorption process is an effective method for the removal of dyes from the effluent. Adsorption process has advantages over other methods because of the clean sludge operation and complete removal of dyes even from the liquid solution. Through adsorption method, pollutants in wastewater will be adsorbed and removed on the surface of a porous material or filter. The main mechanism of adsorption of the dye obtained is spontaneous interactions related charges (Ngadi et al. 2014). Adsorbents have a distinct level of the adsorption capacity (Wang, Z. 2011). While, activated carbon have been widely used as an efficient adsorbent for the removal of organic compounds. However, the high cost of carbon has encouraged researcher to find an alternative low-cost adsorbent. Nowadays, there are many low-cost adsorbents commercially available which are used for the removal of dyes.

Malaysia is one of the largest exporters of palm oil in the international market. One of the major problems inherent in the processing of oil palm fruit is about the management of waste generated during the process (Tan \& Hameed 2010). This industry produces large amounts of solid waste such as oil palm fiber, coconut shell, stone and palm oil empty fruit bunches (EFB) fibers (Lua \& Guo 1998). Through this study, EFB fibers is used as a raw material for the treatment of wastewater from the textile industry.

The purpose of this study is to identify the appropriate treatment and modification of EFB fibers by cationic and anionic surface functionalization. The discoloration of textile effluent has been carried out using modified EFB fibers in kinetics and isotherm adsorption. The comparison between modified fibers are observed through characterization and the efficiency of the adsorbent in the discoloration of batik effluent.

\section{METHODOLOGY}

\section{CHEMICAL MODIFICATION OF EFB FIBERS}

The preparation of the EFB fibers were undergoes similar procedure from previous finding (Sajab et al. 2013). Briefly, EFB fibers (106-500 $\mu \mathrm{m})$ was pretreated using $0.1 \mathrm{M} \mathrm{NaOH}$ at $65^{\circ} \mathrm{C}$ for $1 \mathrm{~h}$, and wash thoroughly until further use.

The cationic functionalization was done by polyethyleneimine (PEI) $\left(\mathrm{M}_{\mathrm{W}} \sim 750,000,50 \mathrm{wt} . \%\right.$ in $\left.\mathrm{H}_{2} \mathrm{O}\right)$. The physical grafting of PEI on EFB was controlled at a temperature of $65^{\circ} \mathrm{C}$ for $6 \mathrm{~h}$ and continue with the crosslinking reaction by glutaraldehyde for $1 \mathrm{~h}$. Whereas, the anionic functionalization was performed by grafting ethylenediaminetetraacetic acid (EDTA) at $50^{\circ} \mathrm{C}$ within $4 \mathrm{~h}$. The modified were washed several times with deionized water and dried in an oven at $130^{\circ} \mathrm{C}$ for 24 hours and stored.

\section{ADSORPTION EXPERIMENT}

Adsorption kinetics was done in a general adsorption experiment procedure (Sajab et al. 2013). Concisely, $0.1 \mathrm{~g}$ of the adsorbents were added in $100 \mathrm{~mL}$ of the batik effluent. The $\mathrm{pH}$ and the temperature were adjusted from $\mathrm{pH} 3,5,7$ and 9 and 20,40 and $60^{\circ} \mathrm{C}$. The experiment was carried out at $250 \mathrm{rpm}$ for $6 \mathrm{~h}$. The final color concentration of the effluent $\left(C_{\mathrm{e}}\right)$ is measured using a UV spectrophotometer. While the amount of color removal in a unit mass of adsorbent at time $\mathrm{t}\left(q_{\mathrm{t}}\right)$ was followed by the equation:

$$
q_{t}=\frac{\left(C_{o}-C_{t}\right)}{m}
$$

where $C_{0}$ is the initial color concentration, $C_{\mathrm{t}}$ is equilibrium color concentration at time $\mathrm{t}(\mathrm{mg} / \mathrm{L}), V$ is the volume of the batik effluent (L) and $m$ is the mass of adsorbent $(\mathrm{g})$.

In adsorption isotherm, the varies of color concentration was prepared in a series of batik effluent dilution. The temperature of the experiment was controlled at 20,40 and $60^{\circ} \mathrm{C}$ by using a water bath shaker. The amount of color has been adsorbed in a unit mass of adsorbent, $q_{\mathrm{e}}(\mathrm{mg} / \mathrm{g})$ was calculated using the following equation:

$$
q_{e}=\frac{\left(C_{o}-C_{e}\right) V}{m}
$$

where $C_{0}$ is the initial color concentration, $C_{\mathrm{e}}$ is equilibrium concentration of dye $(\mathrm{mg} / \mathrm{L}), V$ is the volume of the dye solution $(\mathrm{L})$ and $\mathrm{m}$ is the mass of adsorbent $(\mathrm{g})$.

\section{CHARACTERIZATION}

UV-Vis Spectrophotometer (Spectrum SP-UV 300SRB) was used to characterize the absorption capacity of each sample after running isothermal and kinetics adsorption.

\section{RESULTS AND DISCUSSION}

\section{CHARACTERIZATION}

The spectrophotometer of batik effluent shows in Figure 1(a) presents the limitation of color concentration at different series of dilution. At the maximum wavenumber of $520 \mathrm{~nm}$, this peak represents the chemical composition of chromophore existed in batik effluent. The correlation of the color was set based on the standard concentration of Platinum-Cobalt (PtCo) plotted in Figure 1(b).

\section{DISCOLORATION EFFICIENCY OF MODIFIED EFB}

Based on Figure 2, it can be shown that PEI-EFB is the best modified EFB to absorb batik wastewater effluent compared to NaOH-EFB, EDTA-EFB, and PEI-EFB. The strong ionic 
(a)
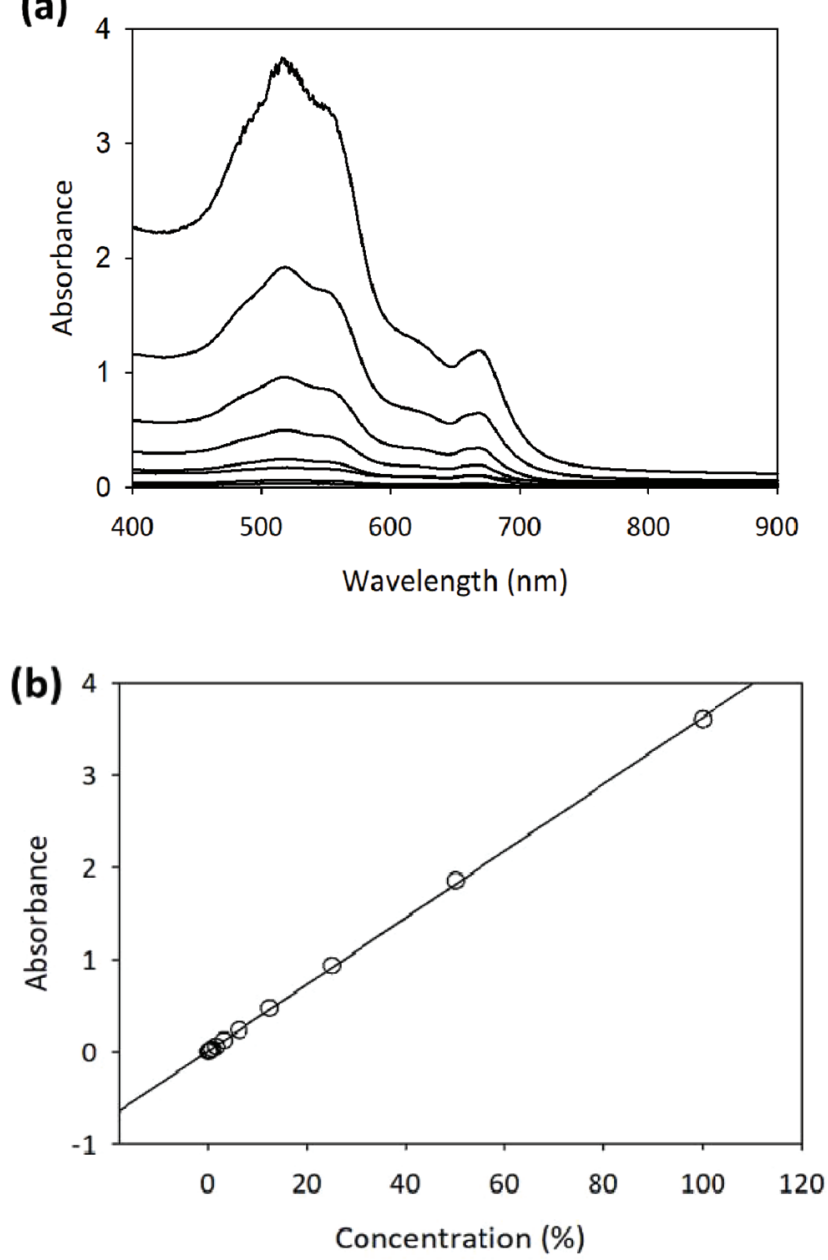

FIGURE 1. The spectrophotometric spectrum of (a) series of batik effluent dilution and (b) the correlation of color at $520 \mathrm{~nm}$

interaction might the possible explanation of the capability of PEI-EFB to attract more color in comparison with other modified EFB fibers. Since EDTA-EFB has been coated with anionic charge, is expected to adsorb more color compared to raw EFB fibers. However, NaOH-EFB fibers with similar anionic charges show slightly higher adsorption performance. This is due to the swelling effect after $\mathrm{NaOH}$ pretreatment has resulted in higher surface area which can be occupied with more adsorbate molecules. While, the cationic charges of amine groups on PEI-EFB gives the highest adsorption capacity through ionic interaction (Sajab et al. 2013). This suggested that the batik effluent collected might contains a high amount of anionic dyes. Subsequently, the modification by PEI on EFB fibers was chosen in the following study.

\section{ADSORPTION KINETICS}

Figure 3(a) illustrated the effect of initial $\mathrm{pH}$ for adsorption using PEI-EFB towards wastewater. At low $\mathrm{pH}$ of 3 , the removal of color was recorded up to $572.3 \mathrm{mg} / \mathrm{g}$. While the increment of the $\mathrm{pH}$, the adsorption capacity was reduced significantly to $142.2,112.5$ and $67.0 \mathrm{mg} / \mathrm{g}$ for $\mathrm{pH} \mathrm{5,7}$ and 9, respectively. The removal of $98.2 \%$ of color at $\mathrm{pH} 3$ (Figure

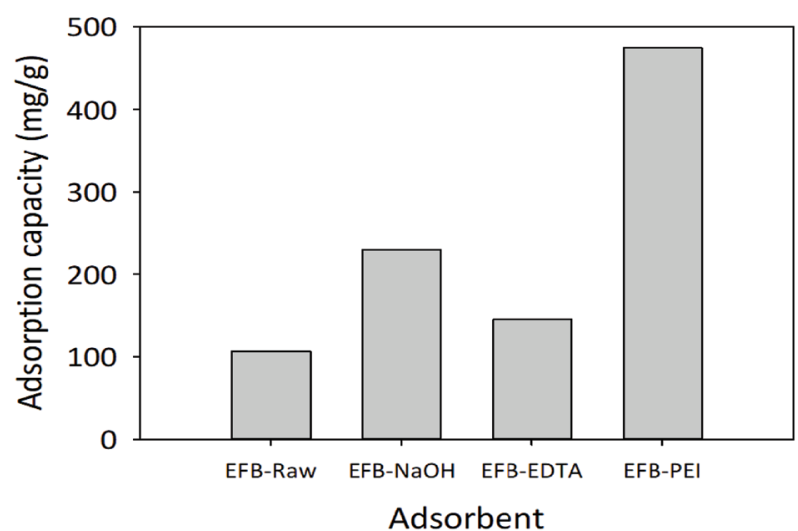

FIGURE 2. The comparison of adsorption capacity by different modification of EFB fibers (temperature: $20^{\circ} \mathrm{C}$; adsorbents dosage: $100 \mathrm{mg} / \mathrm{L} ; \mathrm{pH}: 7)$

3(b)) indicates the low competition between adsorbateadsorbent in comparison with high amount of $\mathrm{OH}^{-}$competing with anionic dye molecules at the higher $\mathrm{pH}$ effluent (Zhong et al. 2011).
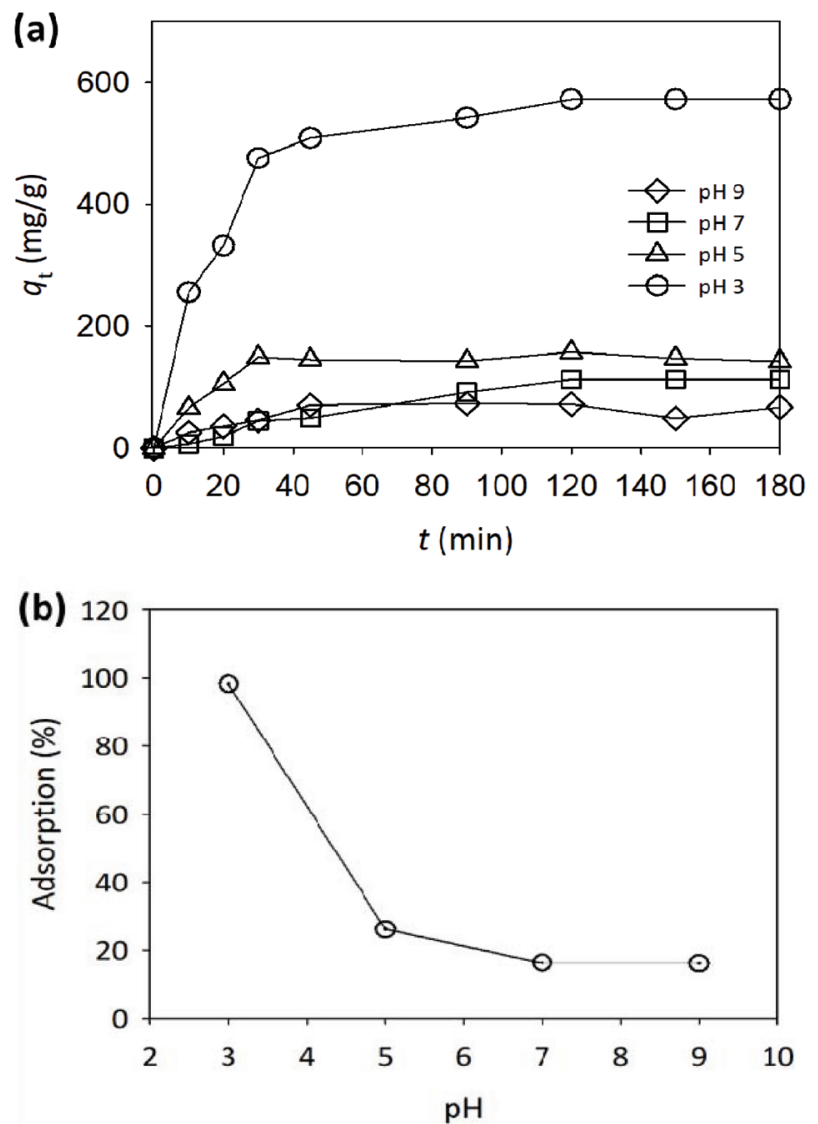

FIGURE 3. The effect of $\mathrm{pH}$ effluent at (a) adsorption kinetics and (b) the removal efficiency (temperature: $20^{\circ} \mathrm{C}$; PEI-EFB fibers dosage: $100 \mathrm{mg} / \mathrm{L} ; \mathrm{pH}: 3-9)$

The effect of initial temperature towards the adsorption of color in batik effluent is shown in Figure 4. However, the fluctuation of adsorption capacity can be observed at 20,40 and $60^{\circ} \mathrm{C}$ of the effluent. The previous study described that 
the exothermic nature of adsorption proven by the decrease of adsorption capacity with an increase of temperature (Rangabhashiyam et al. 2013).

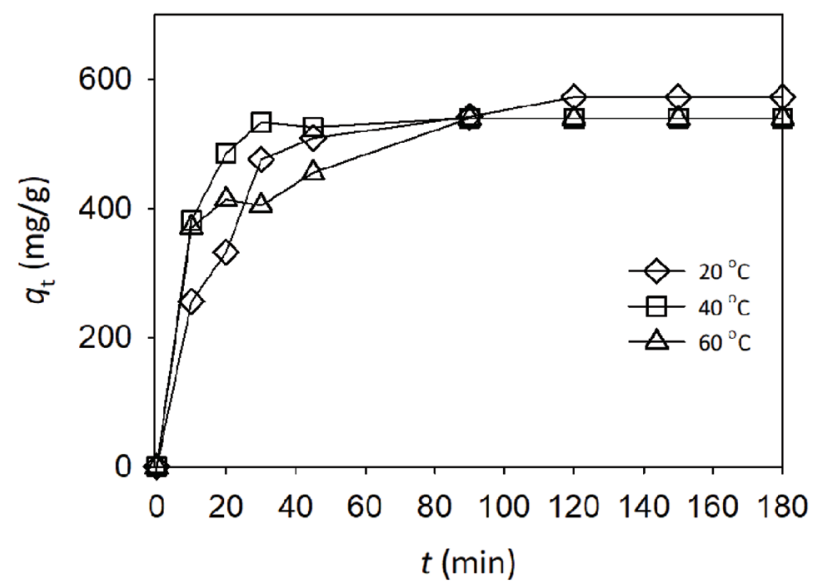

FIGURE 4 . The effect of temperature on the adsorption kinetics of batik effluent (temperature: $20-60^{\circ} \mathrm{C}$; PEI-EFB fibers dosage: $100 \mathrm{mg} / \mathrm{L} ; \mathrm{pH}: 7)$

The mechanism of the adsorption dye on the PEI-EFB was investigated using Pseudo First-order and Pseudo Secondorder. The Pseudo First-order and Pseudo Second-order can be expressed in the Eq. 3 and Eq. 4 (Ho and McKay 1998; Lagergren 1898):

$$
\begin{gathered}
\ln \left(q_{e}-q_{t}\right)=\ln q_{e}-k_{1} t \\
\frac{1}{q_{t}}=\frac{1}{k_{2} q_{e}^{2}}+\frac{1}{q_{e}} t
\end{gathered}
$$

where $k_{1}$ and $k_{2}$ are the rates constant of Pseudo Firstorder and Pseudo Second-order, respectively. Figure 5 shows both of adsorption kinetics models were fitted with experimental color adsorption at $20^{\circ} \mathrm{C}$ using PEI-EFB fibers. In this correlation, Pseudo First-order gave slightly higher correlation at 0.990 in comparison with Pseudo Second-order at 0.985 . Similar results were obtained in a previous study (Duong et al. 2005).

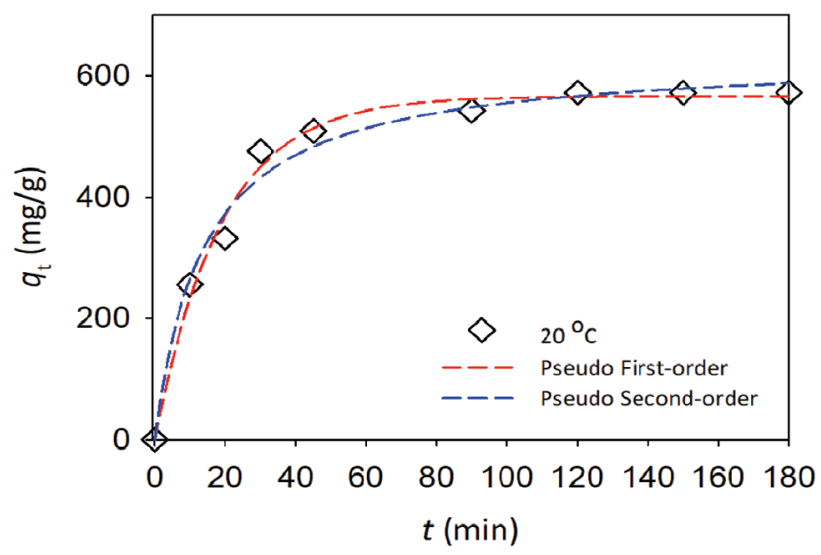

FIGURE 5. Adsorption kinetics models of Pseudo First and Second order (temperature: $20^{\circ} \mathrm{C}$; PEI-EFB fibers dosage: $100 \mathrm{mg} / \mathrm{L} ; \mathrm{pH}: 7$ )
ADSORPTION ISOTHERM

Concisely, the theoretical assumption on the mechanism between adsorbate-adsorbent can be represented by Langmuir and Freundlich isotherm models. The premise of Langmuir model indicates the monolayer interaction between adsorbate molecules and the active surface of the adsorbent. Whereas, Freundlich model assuming the heterogeneous interaction behavior of the adsorbent-adsorbate mechanism. These isotherm models are expressed as (Langmuir 1917; Freundlich 1906),

$$
\begin{gathered}
q_{e}=\frac{Q_{0} b C_{e}}{1+b C_{e}} \\
q_{e}=K_{F} C_{e}^{1 / n_{F}}
\end{gathered}
$$

where $Q_{0}$ is the maximum adsorption capacity per unit mass of adsorbent $(\mathrm{mg} / \mathrm{g})$ and $b$ is a constant related to the adsorption energy $(\mathrm{L} / \mathrm{mg})$. where $K_{\mathrm{F}}$ and $1 / n_{\mathrm{F}}$ are the Freundlich constants, with $K_{\mathrm{F}}$ representing the relative adsorption capacity $((\mathrm{mg} / \mathrm{g})(\mathrm{L} / \mathrm{mg}) 1 / \mathrm{n}))$ of the adsorbent and $n_{\mathrm{F}}$ representing the degree of dependence of adsorption on the equilibrium concentration of color.
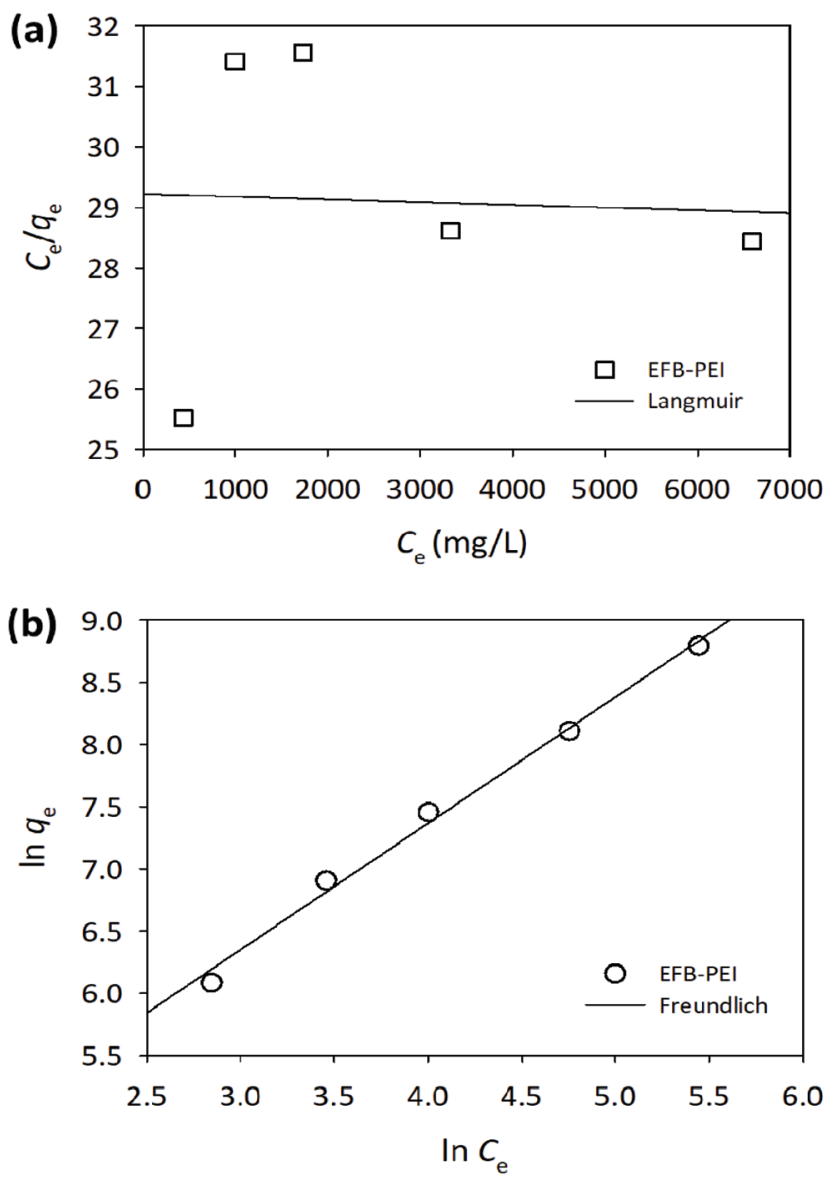

FIGURE 6. Linear regression of adsorption isotherm models of (a) Langmuir and (b) Freundlich (temperature: 20-60 ${ }^{\circ} \mathrm{C}$; PEI-EFB fibers dosage: $100 \mathrm{mg} / \mathrm{L} ; \mathrm{pH}: 7$ ) 
Figure 6(a) shows insignificance correlation line between the experimental data of adsorption and Langmuir model. Whereas, the higher correlation coefficient of $r_{2}$ at 0.993 can be interpreted through the fitted Freundlich model in Figure 6(b). This evaluation indicates a heterogeneous interaction of color molecule and the high branches of PEI might occur as the interaction of adsorbent-adsorbate. The $n$ value calculated in Freundlich model $(1.022>1)$ implies the favorable adsorption of anionic dyes compound on the PEI (Sajab et al. 2013).

\section{CONCLUSION}

The ionic interaction between dyes molecules in the system with the surface-active sites of modified fibers are the main factor in the modification of oil palm EFB fibers for batik effluent discoloration. The modification through a polymeric chain of PEI and EDTA are the essential features for enhancing the cationic and anionic charges on the EFB fibers. Although both modifications are successfully improved the color uptake in batik effluent, PEI-EFB fibers show a vast response in comparison with other modification of the EFB fibers. At low $\mathrm{pH}$ of 3 , the removal of color was recorded up to 572.3 $\mathrm{mg} / \mathrm{g}$, which improved significantly. While the experimental data of the adsorption of color onto PEI-EFB fitted Freundlich isotherm reveal the heterogeneous interaction between adsorbent-adsorbate.

\section{ACKNOWLEDGEMENT}

The authors acknowledge the financial support given by and Universiti Kebangsaan Malaysia for the financial support via the research project grants GGPM-2016-025 and Malaysia Research University Network, MRUN-UKM-2018.

\section{REFERENCES}

Amini, M., Arami, M., Mahmmodi, N. M. \& Akbari, A. 2011. Dye removal from colored textile wastewater using acrylic grafted nanomembrane. Desalination 267 : 107-113.

Banat, I. M., Nigam, P., Singh, D. \& Marchant, R. 1996. Microbial decolorization of textile-dye-containing effluents: a review. Bioresource Technology 58: $217-$ 227.

Deng, S. \& Ting, Y.-P. 2005. Characterization of PEI-modified biomass and biosorption of $\mathrm{Cu}$ (II), $\mathrm{Pb}$ (II) and $\mathrm{Ni}$ (II) Water Research 39: 2167-2177.

Freundlich, H.M.F. 1906. Over the adsorption in solution. The Journal of Physical Chemistry 57A: 385-470.

Ganesh, R., Boardman, G. D. \& Michelson, D. 1994. Fate of azo dyes in sludges. Water Research 28: 1367-1376.

Ho, Y. S. \& McKay, G. 1998. Kinetic models for the sorption of dye from aqueous solution by wood. Process Safety and Environmental Protection 76: 183-191.

Ho, Y.-S., Chiu, W.-T. \& Wang, C.-C. 2005. Regression analysis for the sorption isotherms of basic dyes on sugarcane dust. Bioresource Technology 96: 1285 1291.

Lagergren, S. 1898. About the theory of so-called adsorption of soluble substance. Handlingar 21: 1-39.

Langmuir, I. 1916. The constitution and fundamental properties of solid and liquids. Part 1: Solid. Journal of the American Chemical Society 39(11): 2221-2295.

Ranganathan; K., Karunagaran; K. \& Sharma. D. C. 2007. Recycling of wastewaters of textile dyeing industries using advanced treatment technology and cost analysis - case studies. Resources, Conservation and Recycling 50(3): 306-318.

Kumar, D. P., Mohamed, A. R. \& Bhatia, S. 2002. Wastewater treatment using photocatalyst: destruction of methylene blue from wastewater streams. Jurnal Kejuruteraan 14 17-30.

Lua, A. C. \& Guo, J. 1998. Preparation and characterisation of chars from oil palm waste. Carbon 36(11): 1663-1670.

Ma, H., Zhuo, Q. \& Wang, B. 2009. Electro-catalytic degradation of methylene blue wastewater assisted by Fe2O3-modified kaolin. Chemical Engineering Journal 155: 248-253.

Ngadi, N., Mahmud, M. A., Jusoh, M., Rahman, R. A. \& Alias, H. 2014. Removal of ethyl orange dye using hybrid chitosan and zinc oxide. Jurnal Teknologi 67(1): 47-52.

Rafatullah, M., Sulaiman, O., Hashim, R. \& Ahmad, A. 2010 Adsorption of methylene blue on low-cost adsorbents: a review. Journal of Hazardous Material 177: 70-80.

Rangabhashiyam, S., Anu, N. \& Selvaraju, N. 2013. Sequestration of dye from textile industry wastewater using agricultural waste products as adsorbents. Journal of Environmental Chemical Engineering 1(4): 629641.

Sajab, M. S., Chia, C. H., Zakaria, S. \& Khiew, P. S. 2013 Cationic and anionic modifications of oil palm empty fruit bunch fibers for the removal of dyes from aqueous solutions. Bioresource Technology 128: 571-577.

Tan, I. A. W. \& Hameed, B. H. 2010. Adsorption isoterms, kinetics, thermodynamics and desorption studies of basic dye on activated carbon derived from oil palm empty fruit bunch. Journal of Applied Science 10(21): 2565-2571.

Velmurugan, P., Rathina kumar, V. \& Dhinakaran, G. 2011. Dye removal from aqueous solution using low cost adsorbent. International Journal of International Sciences 1(7): 1492-1503.

Wang, Z., Xue, M., Huang, K. \& Liu, Z. 2011. Textile dyeing wastewater treatment. Advances in Treating Textile Effluent. Intechopen.

Weber, E. J. \& Adams, R. L. 1995. Chemical- and sediment-mediated reduction of azo dye disperse blue 79. Environmental Science and Technology 29: 11631170 .

Wu, C.-H. \& Chern, J.-M. 2006. Kinetics of photocatalytic decomposition of methylene blue. Industrial \& Engineering Chemistry Research 45: 6450-6457. 
Mohd Shaiful Sajab*, Wan Nur Qurratu 'Ainie Wan Manan, Jude Santanaraj, Wan Nor Roslam Wan Isahak

Research Centre for Sustainable Process Technology (CESPRO),

Chemical Engineering Programme,

Faculty of Engineering \& Built Environment,

Universiti Kebangsaan Malaysia,

43600 UKM Bangi, Malaysia.

Chin Hua Chia

Bioresources and Biorefinery Laboratory,

School of Applied Physics,

Faculty of Science and Technology,

Universiti Kebangsaan Malaysia,

43600 UKM Bangi, Malaysia.

*Corresponding author; email: mohdshaiful@ukm.edu.my

Received date: $24^{\text {th }}$ April 2018

Accepted date: $7^{\text {th }}$ August 2018

Online First date: $1^{\text {st }}$ October 2018

Published date: $30^{\text {th }}$ November 2018 